Polonia Sacra $18(2014) \mathrm{nr} 2(35) \cdot$ s. 177-193

\author{
ks. Jan Nowak ${ }^{1}$ \\ Uniwersytet Papieski Jana Pawła II w Krakowie
}

\title{
Książę kardynał Adam Stefan Sapieha jako apostoł miłosierdzia w naszej ojczyźnie
}

\author{
Minęło ponad 10 lat od pielgrzymki św. Jana Pawła II do Sanktuarium \\ Miłosierdzia w Łagiewnikach. W 2002 roku papież przekazał nam orędzie \\ o miłosierdziu i ukazał największych świadków miłosierdzia:
}

Wezwanie do dawania świadectwa miłosierdziu brzmi szczególnie wymownie tu, w umiłowanym Krakowie, nad którym góruje sanktuarium Miłosierdzia Bożego [...]. Tu brzmi to wezwanie znajomo, bo odwołuje się do wielowiekowej tradycji tego miasta, której szczególnym znamieniem była zawsze gotowość do niesienia pomocy potrzebującym. Nie można zapomnieć, że z tej tradycji wyrosło wielu świętych, błogosławionych - kapłanów, osób konsekrowanych i wiernych świeckich - którzy poświęcili swe życie posłudze miłosierdzia. Od biskupa Stanisława, Jadwigi Królowej, Jana Kantego, Piotra Skargi, aż do Brata Alberta, Anieli Salawy i kardynała Sapiehy, kolejne poko-

1 Ks. Jan Nowak - spowiednik w Sanktuarium Bożego Miłosierdzia w Krakowie, postulator procesu beatyfikacyjnego sługi Bożego ks. Władysława Bukowińskiego, autor Positio o heroiczności cnót sługi Bożego ks. Władysława Bukowińskiego, był ojcem duchownym w seminariach duchownych w Koszalinie i Krakowie oraz Międzydiecezjalnym Wyższym Seminarium Duchownym w Karagandzie w Kazachstanie. Obronił pracę doktorską Aktualność kaznodziejskiej koncepcji kształtowania sumienia w kazaniach katechizmowych okresu międzywojennego. Jest autorem m.in. następujących pozycji książkowych: Najbliżsi przyjaciele ks. Władysława Bukowińskiego: ks. Bronisław Drzepecki i ks. Józef Kuczyński, Kraków 2009; Świadek. Życie i działalnośćsługi Bożego ks. Władysława Bukowińskiego, Apostoła Kazachstanu, Kraków 2009; Vianney Wschodu. Ks. Władysław Bukowiński, Kraków 2010; Świadkowie miłosierdzia, Kraków 2011; Niezłomny pasterz. Duszpasterstwo ks. Władysława Bukowińskiego w Kazachstanie w latach 1950-1974, Kraków 2013. Opracował Bądźcie świadkami Bożego miłosierdzia: Jan Paweł II do Rodaków, Kraków 1999; Wezwani do zwycięstwa moca miłości. Jana Pawła II teksty o Bożym miłosierdziu wygłoszone w czasie pielgrzymek do Ojczyzny, Kraków 2002. 
lenia wiernych mieszkańców tego miasta podejmowały. Dziś to dziedzictwo zostało przekazane w nasze ręce i nie może pójść w zapomnienie ${ }^{2}$.

Nie można zapomnieć w tym kontekście o osobie kard. Adama Stefana Sapiehy, który od ingresu w marcu 1912 roku do śmierci w roku 1951 ukazywał niezwykłe bogactwo miłosierdzia. Warto przypomnieć, że ponad 100 lat temu na rozpoczęcie posługi w diecezji krakowskiej Sapieha polecił siostrom miłosierdzia przygotowanie obiadu dla trzystu najbiedniejszych mieszkańców Krakowa. Dlatego chcemy podjąć temat dziedzictwa miłosierdzia, wpatrując się w życie księcia kardynała, który ukochał ubogich i cierpiących.

\section{Biogram}

Książę kardynał Adam Stefan Sapieha żył w latach 1867-1951. Pochodził z rodu książęcego księcia Adama Stanisława Sapiehy i Jadwigi z książąt Sanguszków. Był najmłodszy z sześciorga rodzeństwa. Po ukończeniu gimnazjum odbył studia prawnicze w Wiedniu, a następnie w 1890 roku rozpoczął studia na wydziale teologicznym w Innsbrucku, które ukończył w roku 1894 . Równocześnie był alumnem w seminarium lwowskim. W 1893 roku otrzymał święcenia kapłańskie. W 1894 jako kapłan archidiecezji lwowskiej został wikariuszem w Jazłowcu. Po roku wyjechał na studia do Rzymu, które ukończył doktoratem z prawa kanonicznego w roku 1896. W międzyczasie studiował także na Akademii Dyplomatycznej. W roku 1897 został wicerektorem seminarium metropolitalnego we Lwowie. W latach 1906-1911 był szambelanem ojca świętego Piusa X i referentem spraw polskich przy Stolicy Apostolskiej.

Po śmierci kardynała Jana Puzyny 17 grudnia 1911 roku kardynał Sapieha otrzymał sakrę biskupią. 3 marca 1912 roku objął diecezję krakowską. Jako pasterz szczerą miłością otoczył kapłanów i wiernych. Był troskliwym opiekunem. Często powtarzał księżom: „Kochaj Boga i miej otwarte serce dla potrzeby bliźnich"3. Troska o wiernych do końca wypełniała jego codzienne życie:

2 Jan Paweł II, Bóg bogaty w miłosierdzie: Ostatnia pielgrzymka ojca świętego Jana Pawła II do Ojczyzny, Warszawa 2006, s. 55.

B. Przybyszewski, Zarys dziejów diecezji krakowskiej, Kraków 1998, s. 84. 
„Wtedy czuję się biskupem - mawiał - kiedy jestem między ludem”" Wielką miłością otaczał ubogich. W 1913 roku stworzył tzw. komitety parafialne, które w czasie I wojny światowej wspierały potrzebujących - zwłaszcza chorych, ofiary wojny i głodujących. Ponadto w latach 1914-1945 utworzył wiele organizacji charytatywnych, by pomagać ludziom cierpiącym z powodu wielkich klęsk żywiołowych, powodzi, pożarów, wojen i bezrobocia.

Warto zwrócić uwagę na jego wyjątkowe dzieła charytatywne, kiedy ojczyzna odzyskała niepodległość. Należy do nich dom księży katechetów i emerytów przy ulicy św. Marka 10 w Krakowie, którego budowę ukończono w roku 1925. Do budynku seminarium duchownego dobudowano skrzydło południowe z obszerną salą rekreacyjną na parterze. Otwarty w roku 1928 Dom Katolicki (obecnie budynek Filharmonii) był ośrodkiem katolickiej pracy całego miasta.

W roku 1934 powstała Caritas diecezjalna oraz jej parafialne oddziały. Po II wojnie światowej kardynał Sapieha stanął na czele Krajowej Centrali Caritas. Do końca życia był zaangażowany w dzieło miłosierdzia. Odszedł do Pana 23 lipca 1951 roku.

1. Początki pasterzowania ukierunkowanego na ubogich. Listy pasterskie i orędzia w sprawie akcji charytatywnych

17 grudnia 1911 roku biskup Sapieha przyjął sakrę, a 3 marca 1912 roku odbył się jego ingres do katedry wawelskiej. Był kontynuatorem programu miłosierdzia dla wielu pokoleń chrześcijan i duchowieństwa: „Jego dewizą było ora, labora et ama - kochaj Boga, pracuj, miej otwarte serce na potrzeby bliźnich" 5 . Interesowały go potrzeby materialne i duchowe ludzi potrzebujących, zwłaszcza tych najbiedniejszych.

Jego pierwszy list pasterski do duchowieństwa podkreślał konieczność pracy w trudnych czasach demoralizacji i wzywał do miłości pasterskiej: „Sama przez się na tej miłości wykwita też gorliwość pasterska, szukająca

Tamże, s. 85.

Tamże, s. 84. 
dusz przede wszystkim, ale nie zapominająca o stronie ziemskiej człowieka"6. W liście do wiernych pisał o rozluźnieniu więzów rodzinnych wśród diecezjan, zwiększeniu liczby rozwodów, braku poszanowania rodziców przez dzieci oraz zaniedbywaniu obowiązków rodzicielskich przez ojców rodzin. O matkach i żonach pisał w następujący sposób: „Całą siłą, na jakiej opiera się jeszcze to życie rodzinne u nas, to wiara, wielka miłość i wielkie poświęcenie naszych polskich niewiast, matek i żon"7.

Ksiądz kardynał Sapieha troszczył się o biednych, organizując m.in. „w roku 1913 w diecezji komitety parafialne dla ubogich. To już od razu ukazało krakowianom miłosierne serce Sapiehy" ". W obliczu nadchodzącej wojny nakłaniał do świadczenia pomocy w znalezieniu tymczasowego schronienia poszkodowanym? . Wzywał do budowy ochronek dla dzieci, domów opieki dla sierot, biednych i chorych. Przypominał wiernym o szerzeniu dobrej prasy i literatury religijnej ${ }^{10}$. Wydał także szereg odezw zachęcających do ratowania ofiar wojny, głodu, powodzi. Pierwszą z nich była odezwa na Boże Narodzenie 1914 roku. Pisał w niej o dramacie wojny: „Nie pokój na ziemi, ale wojna, straszna wojna, najokrutniejsza, jaką kiedykolwiek ludzkość przechodziła, ta wojna rozszalała się tuż za bramami naszego miasta, wśród naszych wsi i miast"11. Co robić w sytuacji, kiedy całe rodziny pozbawione są dachu nad głową, mienia i środków do życia? Książę odpowiadał: „Wzywamy więc wszystkich, bo sami nie zdołamy uśmierzyć ran tej niebywałej klęski, rodaków żyjących wśród innych narodów, ludzi mających serce, by spieszyli, z czem kto może [...]. Niech więc z Krakowa wyjdzie wołanie i prośba do bliskich i dalekich, by wyciągnęli miłosierną rękę"12.

W 1917 roku Sapieha napisał pierwszy list pasterski na Wielki Post. W ostrych słowach oceniał sytuację religijno-moralną w diecezji. Wskazywał na brak wierności przykazaniom, zwłaszcza na niesprawiedliwość i nieuczci-

Notificationes 1912, nr 3-4, s. 18.

Tamże, s. 27.

Tamże.

E. Florkowski, Listy pasterskie Adama Stefana Sapiehy, [w:] Archidiecezja Krakowska za pasterzowania Adama Stefana Sapiehy, red. ks. J. Wolny, Kraków 1982, s. 266 (Księga Sapieżyńska, 1).

10 Por. B. Przybyszewski, Zarys dziejów diecezji krakowskiej, dz. cyt., s. 86.

11 Notificationes 1915, nr 1, s. 2.

12 Tamże, s. 3. 
wość. Dla wielkiego obrońcy ubogich wartości te formowały podstawę miłosierdzia. Na koniec listu tłumaczył swoje wymagania i ostry ton potrzebą ojcowskiego serca, które wzywa do nawrócenia i zawierzenia Bożemu miłosierdziu:

Wobec tylu cierpień i bólów, jakimi jesteśmy dotknięci, Drodzy Moi, czyż należało zwrócić do Was mowę tak twardą? 0, gdybym nie wierzył w waszą dobrą wolę, gdybym nie spodziewał się, że tak samo też chcecie usunąć wszystko, co może się Bogu nie podobać, z pewnością nie odezwałbym się do Was w ten sposób. Krwawi się jednak serce, widząc tyle zalet, tyle dobrej woli narodu, tyle cierpień poniesionych, tyle darów Bożych w nim złożonych, który jednak z nich nie korzysta, owszem to, co ma najcenniejszego, raczej na zgubę swoją przemienił' ${ }^{13}$.

W następnych listach pasterskich na Wielki Post z lat 1932, 1933 i 1935 również można zauważyć niepokój kardynała z powodu braku wierności prawu Bożemu. Jest w nich jednak także nadzieja i ufność w Boże miłosierdzie. Książę Sapieha wydał stosunkowo niewiele listów pasterskich, gdyż był człowiekiem czynu. Mawiał, że lubi być z ludźmi. Widząc ich cierpienia, biedę i problemy, służył im i czynił dzieła miłosierdzia.

Warto podkreślić, że książę kardynał wielką wagę nadawał tygodniom miłosierdzia. Świadczą o tym dwa przedwojenne orędzia na Tydzień Miłosierdzia w październiku 1937 i 1938 roku. W roku 1937 Tydzień Miłosierdzia obchodzony był pod hasłem Nieśmy pomoc najbiedniejszym. Warto przytoczyć słowa samego księcia metropolity napisane na tę okazję: „My, katolicy nie możemy nigdy zapominać o tym, że miłosierdzie, i to miłosierdzie czynne jest podstawowym obowiązkiem naszej wiary, a zarazem wielką chwałą i wyróżnieniem naszym” ${ }^{14}$. W 1938 roku arcybiskup wzywał „do przynależenia i do czynnej pracy w katolickich organizacjach dobroczynnych”15. W sprawie palących kwestii społecznych oświadczył, że kluczem jest poszanowanie prawa Bożego i stosowanie zasad chrześcijańskich w życiu społecznym: „Robotników zachęca do tego, by łączyli się w organizacjach katolickich dla obronnych swych uprawnień"16.

\footnotetext{
Notificationes 1917, nr 2-3, s. 13.

Notificationes 1937, nr 11, s. 119.

Notificationes 1938, nr 9-10, s. 113.

16 Por. E. Florkowski, Listy pasterskie Adama Stefana Sapiehy, dz. cyt., s. 181.
} 


\section{Miłosierdzie wobec wysiedlonych i uchodźców}

Na początku I wojny światowej Kraków został zaatakowany przez Rosjan. Zarządzono akcję ewakuacyjną tych, którzy nie mieli na tyle żywności, aby przeżyć trzy miesiące. Jeszcze w 1914 roku Kraków opuściło około 100 tysięcy ludzi ${ }^{17}$. Ponownej ewakuacji chciano dokonać na początku roku 1915, ale nie doszło do niej, gdyż Rosjanie się wycofali. Biskup od początku wojny wzywał wiernych do modlitwy, a księży do organizowania pomocy najbardziej potrzebującym, zarówno ewakuowanym, jaki i tym, którzy pozostali. Zorganizowano gwiazdkę i zbiórkę dla uchodźców. Sam biskup odwiedzał uchodźców ${ }^{18}$. Od polskich posłów domagał się troski o poprawę bytu ewakuowanych. Błogosławił powstałemu Komitetowi Doraźnej Pomocy dla Ewakuowanych, który na dworcu kolejowym rozdawał żywność, ciepłą odzież i bieliznę. Komitet docierał do baraków w Choceniu, gdzie znaleźli się przesiedleńcy ${ }^{19}$. Stworzono wówczas wiele sekcji komitetu, które pomagały ewakuowanym.

Największą organizacją dobroczynną założoną w tym okresie przez Sapiehę był Książęco-Biskupi Komitet (KBK), którego celem było „niesienie pomocy ludności, której miejsce zamieszkania zalała fala wojsk walczących, aby ją uchronić od zimna i głodu przez dostarczenie potrzebnych artykułów spożywczych i towarów, przez zakładanie sklepów i składnic, otoczyć dzieci opuszczone i osierocone, zająć się ochroną ludności przeciw chorobom”20.

Komitet niósł doraźną pomoc mieszkańcom Galicji i Królestwa, ofiarom wojny i różnych chorób. Szczególną troską objęto chore dzieci. W odezwie w sprawie opieki nad sierotami wojennymi kardynał Sapieha prosił, aby rodziny zapewniły wychowanie ofiarom wojny, by w przyszłości dzieci te były uczciwymi pracownikami, a nie ciężarem dla społeczeństwa. Nad wieloma sierotami rozpostarł opiekę Krakowski Komitet Opieki nad Sierotami Wojennymi. W dziele tym ogromną rolę odgrywali księża, którzy troszczyli

17 Por. ks. A. Baciński, Działalność charytatywna Adama Stefana Sapiehy do roku 1918, [w:] Archidiecezja Krakowska za pasterzowania Adama Stefana Sapiehy, dz. cyt., s. 267.

18 Por. tamże.

19 Por. W. Wróbel, Troska biskupa Adama Sapiehy o wysiedlonych i uchodźców w latach 19141916, Kraków 1999, s. 29-37.

20 Tamże, s. 44. 
się o potrzeby materialne i duchowe opuszczonych dzieci. Organizowali oni duszpasterstwo sakramentalne i katechezę. Książę arcybiskup zabiegał o to w swoich odezwach i dziękował księżom, którzy pomagali przesiedleńcom²1.

W odpowiedzi na odezwy kardynała Sapiehy powstał Generalny Komitet Pomocy dla Ofiar Wojny w Polsce. Został on założony na emigracji przez Henryka Sienkiewicza, Ignacego Paderewskiego i Antoniego Osuchowskiego. Komitety powstawały w całym kraju. Ich działalność sięgała aż po Stany Zjednoczone. W tym dziele komitety były również wspomagane przez Stolicę Apostolską 22 .

Powstawało wiele delegacji Komitetu, między innymi w Wiedniu i Pradze. Komitet Vevey przesłał „na cele KBK 15 wagonów mleka skondensowanego o wartości 173843 koron, 7 wagonów mąki o wartości 16675 koron oraz 3 wagony tłuszczów i odzieży zakupionej w Danii”"23. Godlewski podkreślał rolę biskupa w działalności komitetu: „Książę biskup Sapieha był istotnie nie tylko przewodniczącym komitetu: każdy, kto w tym zespole pracował, pamięta i czuł przez cały czas tej pracy, że on był jej duszą, inicjatorem rozlicznych poczynań, a interesował się naprawdę nawet najdrobniejszymi szczegółami działalności, starał się wszystkim współpracownikom ułatwić usuwanie trudności w pracy"24.

Ogromną rolę w dziele pomocy ewakuowanym odegrały siostry zakonne. Dzięki zabiegom księcia biskupa już z pierwszymi transportami do Chocenia wyjechało pięć sióstr służebniczek miłosierdzia, które zajęły się prowadzeniem ochronki dla dzieci. Opiekowały się także chorymi w szpitalu ${ }^{25}$. Z inicjatywy KBK po wojnie siostry serafitki zorganizowały baraki dla uchodźców w Oświęcimiu ${ }^{26}$. W ten sposób biskup Sapieha wyszedł naprzeciw wielkim potrzebom uchodźców.

Od roku 1915 część uchodźców mogła wrócić na tereny Galicji wyzwolone przez armię austriacką, a w 1918 roku wrócili wszyscy pozostali. Niestety wie-

21 Tamże, s. 88-97.

22 Por. ks. A. Baciński, Działalność charytatywna Adama Stefana Sapiehy do roku 1918, dz. cyt., s. 268 .

Tamże, s. 271.

Tamże, s. 269.

Por. W. Wróbel, Troska biskupa Adama..., dz. cyt., s. 98.

Por. tamże, s. 101. 
lu z nich zmarło na skutek chorób, głodu i zimna ${ }^{27}$. Wśród ofiar były głównie dzieci. Biskupowi nigdy nie zabrakło miłosierdzia. Ks. prof. Przybyszewski podsumował jego służbę w następujący sposób: „Ogromny talent organizatorski biskupa Sapiehy ujawnił się przy kierowaniu zakrojoną na wielką skalę akcją miłosierdzia"28. Widoczne było to poprzez angażowanie ludzi w akcje charytatywne ${ }^{29} \mathrm{w}$ okresie I i II wojny światowej.

\section{Dzieła dobroczynne w okresie międzywojennym}

Po I wojnie w diecezji działało około stu towarzystw dobroczynnych. Powstawały one w obliczu nowych trudności, którymi były bieda, głód i drożyzna. W 1923 roku ukazała się ulotka zachęcająca do niesienia pomocy głodnym. Powstał Ratunkowy Komitet Biskupi dla Niesienia Pomocy Biednym (RKB). W 1925 roku książę kardynał wydał Odezwę w sprawie klęski powodzi, w której pisał: „Ścieśnijmy się w wydatkach naszych, aby każdy z nas mógł złożyć na ołtarzu sprawy publicznej [...]. Jeśli chcemy, by Pan Bóg błogosławieństwo dał, bądźmy miłosiernymi i dobrymi dla naszych bliźnich"30. W 1926 roku powołał on Książęco-Metropolitalny Komitet Pomocy dla Dotkniętych Klęską Bezrobocia (KMK). Osiem kuchni na terenie Krakowa wydawało 3400 obiadów dziennie. Od 15 stycznia do 18 kwietnia wydano w Krakowie 244524 bezpłatnych obiadów, w tym 45638 obiadów dla pracowników umysłowych oraz 198866 dla fizycznych. W czasie szczególnie ciężkiej zimy w 1929 roku w styczniu i w lutym powołany został Komitet Pomocy Dotkniętych Klęską Mrozów, który zaopatrywał potrzebujących w węgiel ${ }^{31}$. W lutym 1931 roku działalność rozpoczął Komitet Pomocy Głodnym. W czterech kuchniach na terenie Krakowa wydawał on posiłki bezrobotnym, którzy nie pobierali ustawowego zasiłku, a także ubogim obarczonym liczną rodziną. W 1931 roku w orędziu do organizacji katolickich kardynał Sapieha pi-

\footnotetext{
27 Por. tamże, s. 102-103.

28 B. Przybyszewski, Zarys dziejów diecezji krakowskiej, dz. cyt., s. 86-87.

29 Por. tamże, s. 87.

30 Notificationes 1925, nr 46, s. 18.

31 M. Świątecka, Adam Stefan Sapieha organizator dobroczynności, [w:] Archidiecezja Krakowska za pasterzowania Adama Stefana Sapiehy, dz. cyt., s. 279.
} 
sał, że „nie tylko z jednej miejscowości lub jednego kraju, ale z całego świata dochodzi nas wieść o biedzie i załamaniu wszelkiego gospodarstwa. [...] Katastrofa jest taka wielka, że nie możemy nawet o tym myśleć, by należycie jej zapobiec. Nie wolno nam jednak stanąć z załamanymi rękami i ulec rozpaczy. Chrześcijańskie miłosierdzie nakazuje nam zrobić wszystko, to co jest w naszej mocy, a ufność w Opatrzność Bożą winna dać nam siły, by stanąć do akcji ratunkowej"32.

Podczas zimy 1932/1933, gdy zdawało się, że z braku funduszy nie uda się już rozdawać obiadów dla biednych, w lutym 1933 roku Arcybiskupi Komitet Ratunkowy przy współpracy innych towarzystw dobroczynnych przeprowadził kwestę w mieszkaniach i lokalach publicznych, co przyniosło bardzo dobre efekty. W ciągu zimy AKR wydał 176776 bezpłatnych obiadów dla pracowników fizycznych i 19730 dla umysłowych. Na taki obiad składały się zupa, kawałek mięsa i chleba. W latach następnych powtarzano takie akcje wydawania obiadów. Powstały również komitety obrony bezrobotnych, ponieważ wzrastała liczba ludzi pozbawionych pracy. W 1931 roku arcybiskup założył Komitet Pomocy Biednym.

W 1934 roku kardynał Sapieha wydał odezwę w sprawie powodzi. Znów poruszyła ona serca krakowian. Kardynał pisał o reakcji ludzi na jego apel o pomoc: „Na potęgę rozszalałej powodzi odezwała się dobroczynna moc serca ludzkiego, miłosierdzia braterskiego, spełnienia zaszczytnego obowiązku społecznego [...] wzajemna bowiem miłość braterska jest najdoskonalszym wykonaniem woli Bożej" ${ }^{33}$. Wskazywał na uczynki miłosierdzia, podkreślając zwłaszcza wielką wartość przebaczenia: „Zatrzeć trzeba dawne porachunki, wygnać wszystko, co rani wzajemne stosunki, co ma znamię niesprawiedliwości lub nienawiści [...]. Śpieszmy więc przede wszystkim my, cośmy zostali uchronieni od nieszczęścia [...]. Otrzeć nam trzeba łzy nieszczęsnych ojców i matek, pozbawionych wszystkiego, co posiadali, nakarmić i przyodziać zgłodniałe i nagie dzieci" ${ }^{34}$.

Kościół polski chciał stworzyć jeden główny ośrodek dyspozycyjny, co sprawiłoby, że świadczona pomoc byłaby bardziej skuteczna. Prymas Hlond

\footnotetext{
32 „Dzwon Niedzielny” 7 (1931), nr 33, s. 517-518.

33 Notificationes 1934, nr 7, s. 112.

34 Tamże.
} 
wprowadził we wszystkich diecezjach związki instytucji dobroczynnych (Caritas). W odezwie z 15 stycznia 1934 roku metropolita pisał:

Związek Caritas ma łączyć jakby w jednym ognisku wszystkie wysiłki dobroczynności katolickiej. Ma być centralą dobroczynności diecezjalnej. Toteż wszystkie katolickie stowarzyszenia, instytucje i zakłady dobroczynne, wychowawcze i opiekuńcze winny przystąpić do tegoż Związku w charakterze członków [...]. Spodziewając się, że ze zjednoczenia i wzajemnej współpracy także w akcji charytatywnej wynikną wielkie korzyści dla cierpiącej ludzkości, zachęcamy bardzo gorąco [...] do popierania Związku Caritas tak moralnie, jak i też materialnie oraz do usilnej pracy na polu zorganizowania miłosierdzia ${ }^{35}$.

W tym samym roku powstała Caritas krakowska. Warto zaznaczyć, że parafialne oddziały Caritas działały już od 1930 roku. Dziełu temu patronował kardynał Sapieha. Wspierał je swoją obecnością, życzliwością i modlitwą.

Kardynał Sapieha pomagał również innym diecezjom. W roku 1936 zgodził się na na trzyletni wyjazd ks. Władysława Bukowińskiego, dzisiaj sługi Bożego, do diecezji łuckiej. Był to czyn miłosierdzia, gdyż młoda diecezja w Łucku potrzebowała kapłana. 11 czerwca 1939 roku ks. Bukowiński poprosił o udzielenie ekskardynacji z archidiecezji krakowskiej do diecezji łuckiej. W piśmie do Kurii w Krakowie uzasadniał tę prośbę w następujący sposób:

Za łaskawą zgodą Najdostojniejszego Księcia Metropolity otrzymałem od sierpnia 1936 r. trzyletni urlop na rozpoczęcie pracy na terenie kresowej diecezji łuckiej. Pracę tę prowadzę nieprzerwanie od trzech lat, przy czym od roku pracuję na odpowiedzialnym kierowniczym stanowisku diecezjalnego sekretarza Akcji Katolickiej. Obecna praca moja obejmuje swym zasięgiem cały Wołyń i część Polesia. Jest rzeczą pożądaną, bym mógł tę pracę dalej prowadzić i rozwijać ${ }^{36}$.

Książę Sapieha wyraził zgodę na jego wyjazd.

Nie sposób wyliczyć wszystkich dzieł księdza kardynała. Podczas jubileuszu dwudziestopięciolecia biskupstwa w 1936 roku nadano mu honorowe obywatelstwo miasta Krakowa. Jednak największym odznaczeniem był fakt, że stał się on żywym symbolem miłosierdzia. Nazywano go Wielkim Jałmużnikiem ${ }^{37}$.

\footnotetext{
35 Notificationes 1934, nr 1, s. 1-2.

36 Archiwum Kurii Metropolitalnej w Krakowie, Pers B.

37 Por. M. Świątecka, Adam Stefan Sapieha organizator dobroczynności, dz. cyt., s. 289.
} 


\section{Miłosierdzie arcybiskupa podczas okupacji niemieckiej.}

Jeszcze przed wkroczeniem Niemców do Krakowa najwybitniejsze osoby krakowskiego środowiska naukowego i społecznego powołały Obywatelski Komitet Pomocy (OKP). Komitet świadczył pomoc zwłaszcza przesiedleńcom i ludziom pozbawionym środków do życia. Drugim nurtem działalności charytatywnej było utworzenie Rady Głównej Opiekuńczej (RGO). Rozpoczęła ona swą działalność w 1940 roku. Mimo że arcybiskup nie należał do założycieli i nie uczestniczył w jej pracach, to organizacja ta pozostawała przez cały czas pod jego duchowym zwierzchnictwem. Sam arcybiskup Sapieha często występował w jej obronie wobec władz niemieckich ${ }^{38}$. Caritas nie mogła działać sama, ponieważ rozwiązano stowarzyszenia. Organizacja utrzymała się ze względu na podporządkowanie jej RGO. Dalej wydawano posiłki, rozdzielano odzież, buty, pościel, żywność i węgiel. Wielką pomocą były dary pieniężne i rzeczowe zbierane w parafiach ${ }^{39}$.

7 października 1939 roku kardynał Sapieha ogłosił list pasterski, w którym pisał: „Ludność potrzebuje podniety do pracy, pociechy i ukojenia w cierpieniu, wreszcie obrony przed rozpaczą" ${ }^{40}$. Wspólnie z RGO interweniował w sprawie Polaków, którzy byli wywiezieni na roboty do Niemiec i pozbawieni opieki duchowej. Pisał w tej sprawie do Watykanu, do Hansa Franka, do biskupa Wrocławia kard. Adolfa Bertrama i kard. Konrada von Preysinga, biskupa Berlina. Do robotników z Polski wysyłał listy z okazji Bożego Narodzenia ${ }^{41}$. Poparł kapelana AK. W dokumentach można znaleźć potwierdzenie wsparcia, którego udzielał: „Zachowały się przekazy wskazujące, że metropolita skierował kapelana do jednego z oddziałów, innemu przez łączników przekazał lekarstwa; że brał udział w ukrywaniu osób poszukiwanych i zagrożonych przez gestapo"42.

Należy podkreślić, że książę kardynał wykazywał niesłychaną odwagę wobec hitlerowców. Był chyba jedynym człowiekiem w ojczyźnie, z którym Niemcy musieli się liczyć.

\footnotetext{
38 Por. Książę niezłomny, red. R. Bogacz, Kraków 2001, s. 115-118.

39 Por. J. Kracik, G. Ryś, Dziesięć wieków diecezji krakowskiej, Kraków 1998, s. 211.

40 J. Czajowski, Kardynat Adam Stefan Sapieha, Wrocław 1997, s. 150.

41 Por. tamże, s. 154.

42 Tamże, s. 159.
} 


\section{Wielkie dzieło miłosierdzia \\ w rękach kardynała Sapiehy w powojennej Polsce}

Episkopat Polski zebrany na konferencji w Częstochowie w 1945 roku powołał arcybiskupa Sapiehę na przewodniczącego komisji episkopatu dla spraw charytatywnych i podjął uchwałę o ustanowieniu Krajowej Centrali Caritas z siedzibą w Krakowie. Statut Centrali, podobnie jak i innych związków diecezjalnych, został pomyślany tak, by one mogły zachować charakter pomocniczy. Praca Centrali i związków opierała się na założeniu, że najważniejsze jest działanie. Organizacje nie zaniedbywały pracy wychowawczej, formacyjnej czy wydawniczej. Autorytet przewodniczącego komisji zachęcał do duchowej współpracy również wielu wybitnych ludzi duchownych i świeckich.

Osoba Sapiehy budziła podziw w społeczeństwie i mobilizowała ludzi do działania zarówno w Polsce, jak i poza jej granicami. Powołanie się na jego osobę uruchamiało różne instancje społeczne i administracyjne, otwierało gabinety ministerialne i ułatwiało rozwiązanie pozornie najtrudniejszych spraw. W tym czasie były także organizowane dzieła pomocy materialnej za granicą, zwłaszcza w Ameryce. Do tego celu organizowano złożoną strukturę pomocników. Ponadto wydawano szereg czasopism, organizowano dni skupienia i konferencje.

Kardynał był tak zaangażowany w działalność charytatywną, że przyleciał samolotem do Gdyni, żeby zobaczyć, jak zorganizowany jest odbiór darów, by odwiedzić magazyny i sprawdzić, jak są realizowane rozdzielniki. Przede wszystkim jednak rozmawiał z ludźmi. Interesował się pracą charytatywną na terenie Krakowa, ponieważ miasto skupiało ogromną liczbę różnego rodzaju instytucji dobroczynnych.

Po II wojnie światowej kardynał Sapieha organizował następne Tygodnie Miłosierdzia. Hasło pierwszego z nich (w roku 1945) brzmiało Polaku, miej serce. W roku 1947 odezwa na Tydzień Miłosierdzia miała tytuł Ratujmy człowie$k a$. Istotne w tych powojennych Tygodniach Miłosierdzia było to, by informacje docierały do wszystkich diecezji nie tylko przez komunikaty biskupie, ale także przez afisze, prasę, kazania, nabożeństwa, akademie i co najważniejsze - przez dzielenie się z potrzebującymi. Refleksja nad tym Tygodniem Miłosierdzia została zapisana w następujących słowach: „Ratujmy człowieka nieszczęśliwego, którego zowie się «niepotrzebnym», zawadzającym, bez- 
użytecznym ze względu na starość, chorobę czy kalectwo"43. Książę kardynał odwoływał się do słów Pana Jezusa: „Coście uczynili jednemu z braci moich najmniejszych, mnieście uczynili" (Mt 25, 40). Ponadto wzywał do modlitwy i błogosławił wszystkim, którzy zaangażują się w działalność charytatywną całym sercem. Na koniec orędzia na Tydzień Miłosierdzia zacytował słowa Skargi: „Boże, porusz ludzkie serca, aby gorącą miłością brali się do czynienia dobrych uczynków i opatrywania nędzy ludzkiej, aby nasze nędze duchowe i świeckie Pan Bóg opatrywać raczył!"44.

Z perspektywy lat widać, że książę Sapieha był całkowicie oddany czynnemu miłosierdziu. Tej postawie, zwłaszcza wobec najbiedniejszych i opuszczonych, dał wyraz w najtragiczniejszych okresach swego pasterzowania. W jednym z ostatnich listów z maja 1951 roku, skierowanym do księży, precyzuje główne zasady miłosierdzia:

Wielkie przykazanie bliźniego i miłosierdzia należą takściśle do istoty Kościoła Bożego na ziemi, że bez nich ten Kościół byłby tylko kultem bez treści wewnętrznej i bez życia, jak religia, chociażby najszlachetniejsza, bez kultu Boga i Jego miłości, byłyby niczym innym, jak tylko jakimś nieudanym i mglistym systemem etycznym. A my nie chcemy być ani czystym kultem, ani tylko systemem etycznym - chcemy być prawdziwym Kościołem ${ }^{45}$.

List ten był napisany po zlikwidowaniu przez władze państwowe w roku 1950 Krajowej Centrali Caritas oraz wszystkich związków diecezjalnych. Stanowił on wezwanie do pracy charytatywnej, która jest jednym z najbardziej istotnych elementów posługi Kościoła: „Prawdziwy i żywy Kościół Chrystusowy musi tedy rozlewać na zewnątrz miłość bliźniego i miłosierdzie swoich kapłanów i swoich członków świeckich. Nawet wówczas, gdy zabraknie stowarzyszeń charytatywnych" ${ }^{46}$.

Organizacje dobroczynne miały działać w oparciu o wiarę. Tak o tym pisał kard. Sapieha na dwudziestopięciolecie swego biskupiego posługiwania:

Miłosierdzie chrześcijańskie i to wszystko, co mieści się w dzisiejszym pojęciu ak-

cji charytatywnej, leży u podstaw ideowej wielkiej i bezcennej spuścizny Zbawiciela

\footnotetext{
43 „Caritas” 3 (1947) nr 10, s. 245.

44 Tamże,

$45 \quad$ Notificationes 1951, nr 5, s. 77-78.

46 Tamże.
} 
świata. Dlatego to akcja charytatywna zrosła się najściślej i nierozerwalnie z tradycją

Kościoła św., a pierwszymi jej organizatorami byli apostołowie, to jest pierwsi biskupi ${ }^{47}$.

Wiedział dobrze, że miłosierdzie wymaga pracy wewnętrznej i wysokiego poziomu moralnego. Dążył do tego, by przez komitety parafialne przyczynić się do jedności Kościoła diecezjalnego. Występował przeciwko chciwości i zazdrości, a podkreślał bezinteresowność. Powtarzał, że praca charytatywna przynosi owoce tylko wówczas, gdy jest oparta na ofiarnej miłości Chrystusa ${ }^{48}$.

Wymagania, które stawiał sobie i innym, wynikały z osobistego przekonania i zaangażowania. Znany był z tego, że codziennie spacerował po Krakowie, wstępując do zakładów dla ubogich, z którymi zasiadał do wspólnego stołu. Często bywał na uroczystościach wśród chorych. Wiedzieli, że mają w biskupie swego niezawodnego opiekuna. Jego mieszkanie na Franciszkańskiej było bardzo skromne, a prosty, pogodny i bezpośredni styl bycia sprawiał, że spotkania w domu biskupim napełniały wszystkich wewnętrzną siłą. Samego zaś gubernatora Franka przyjął czarnym chlebem i czarną kawą, podkreślając, że tak żyją w Krakowie on i jego ubodzy.

\section{Podsumowanie}

Kardynał Sapieha żył w ciężkich czasach, przeżył dwie wojny światowe. Umiał jednak rozwiązywać problemy w duchu wiary. To właśnie w niej należy widzieć klucz do zrozumienia jego działalności pasterskiej, patriotycznej, a nawet politycznej. Interesowało go duszpasterstwo i pomoc potrzebującym. Był niezłomny w trosce o biednych, opuszczonych i doświadczanych przez los.

Dzięki swoim umiejętnościom biskup Sapieha rozwiązywał najtrudniejsze problemy społeczne. Warto podkreślić, że był to przede wszystkim wspaniały organizator, który zawsze realizował program ewangeliczny. Swoje działania opierał na wierze w Opatrzność. Wiedział, że Ona nigdy go nie zawiedzie. Jego drugą godną zauważenia cechą była umiejętność zaangażo-

47 Notificationes 1936, nr 12, s. 152.

48 Por. M. Świątecka, Adam Stefan Sapieha organizator dobroczynności, dz. cyt., s. 286-287. 
wania ogromnej liczby katolików o wysokim poziomie moralnym w dzieła pomocowe. Tworzył w ten sposób komitety elit troszczących się o ducha Bożego. Zawsze mobilizował ludzi po to, aby ratować bliźnich w potrzebie. Najważniejszy był człowiek, jego godność, cierpienie, samotność i konkretny problem związany z brakiem żywności czy mieszkania. Ten wspaniały organizator docierał do wielu instytucji i głów państw na całym świecie. Dzięki temu stworzył wiele środowisk miłosierdzia.

Jego wizja duszpasterstwa, społeczeństwa i polityki była ściśle związana z wypełnianiem uczynków miłosierdzia. Wielki Jałmużnik pierwszej połowy XX wieku jest przykładem dla współczesnego świata. Wzywa do przyjrzenia się programom społecznym, państwowym, a przede wszystkim parafialnym i rodzinnym. Skłania do refleksji, czy mają one wymiar miłosierdzia i czy ludzie współcześni nie stali się obojętni na potrzeby drugiego człowieka. Warto podkreślić, że św. Janowi Pawłowi II bardzo zależało, aby ukazać wielkość kard. Sapiehy. Jego wzór ma bowiem wzywać współczesnych ludzi do umiłowania bliźnich, które stanowi istotę chrześcijaństwa. 
ks. Jan Nowak

\section{Summary}

\section{Cardinal Adam Stefan Sapieha as an apostle of mercy in Poland}

Adam Stefan Sapieha lived from 1867 to 1951. The 100th anniversary of his episcopal ordination creates an opportunity to present his religious and social activity. His great work was based on the ability to mobilize people who were spiritually prepared to help others.

Sapieha came from a princely family and was the youngest of six children. After finishing high school he studied law in Vienna. In 1890 he joined the theological faculty in Innsbruck. At the same time he was an alumnus of the seminary in Lviv. He was ordained priest in 1893. After 18 years he was ordained bishop and took pastoral diocese of Cracow. Thanks to his care Cracow became a city of mercy.

Cardinal Sapieha cared for priests and their parishioners. The concern for the poorest people filled his daily life. He established parish committees and strived to alleviate the plight of workers. Moreover, he encouraged believers to unite in Catholic organizations. He set up charities to help people affected by natural disasters, war and unemployment. After World War II cardinal Sapieha became the head of the National Headquarters of Caritas. Until the end of his life he was involved in charity work, which made other people follow his example.

Keywords: mercy, faith, nation

\section{Streszczenie}

Adam Stefan Sapieha żył w latach 1867-1951. Setna rocznica jego święceń biskupich jest okazją do przedstawienia jego religijnej i społecznej działalności. Jego wielką zasługą była umiejętność duchowego przygotowania do pomocy innym.

Był najmłodszy z sześciorga rodzeństwa. Po ukończeniu gimnazjum odbył studia prawnicze w Wiedniu, a następnie w roku 1890 rozpoczął studia na wydziale teologicznym w Innsbrucku. Równocześnie był alumnem w seminarium lwowskim. W 1893 roku otrzymał święcenia kapłańskie. Po 18 latach przyjął sakrę biskupią i został pasterzem diecezji krakowskiej. Dzięki jego trosce Kraków został miastem miłosierdzia.

Kardynał Sapieha dbał o kapłanów i wiernych swojej diecezji. Opieka nad najsłabszymi wypełniała jego codzienne życie. Tworzył komitety parafialne i walczył o poprawę życia najuboższych robotników. Ponadto zachęcał wiernych do jednoczenia się w organizacjach katolickich. Tworzył organizacje charytatywne pomagające ludziom dotkniętym przez katastrofy, wojnę i bezrobocie.Po II wojnie światowej kardynał Sapieha stał na czele Krajowej Centrali Caritas. Do końca życia angażował się w dzieło miłosierdzia i był autorytetem dla wszystkich, którzy chcieli podążać za jego przykładem.

Słowa kluczowe: miłosierdzie, ufność, naród 


\section{Bibiliografia}

Archidiecezja Krakowska za pasterzowania Adama Stefana Sapiehy, red. ks. J. Wolny, Kraków 1982 (Księga Sapieżyńska, 1).

Jan Paweł II, Bóg bogaty w miłosierdzie: ostatnia pielgrzymka Ojca świętego Jana Pawła II do Ojczyzny, Warszawa 2006.

Przybyszewski B., Zarys dziejów diecezji krakowskiej, Kraków 1998.

Czajowski J., Kardynał Adam Stefan Sapieha, Wrocław 1997.

Kracik J., Ryś G., Dziesięć wieków diecezji krakowskiej, Kraków 1998.

Książę niezłomny, red. R. Bogacz, Kraków 2001.

Wróbel W., Troska biskupa Adama Sapiehy o wysiedlonych i uchodźców w latach 19141916, Kraków 1999. 